\title{
USULAN PERBAIKAN PELAYANAN DI KEDAI KOPI SANG ESOEN PADA MASA PANDEMI COVID-19 MENGGUNAKAN METODE SERVICE QUALITY DAN QUALITY FUNCTION DEPLOYMENT
}

\author{
Nur Qomaruddin Rafli ${ }^{1}$, Dzakiyah Widyaningrum ${ }^{2}$, dan Moh. Jufriyanto ${ }^{3}$ \\ Program Studi Teknik Industri, Fakultas Teknik, Universitas Muhammadiyah Gresik \\ Jl. Sumatera 101 GKB, Gresik 61121, Indonesia \\ e-mail :nqomaruddinrafli@gmail.com
}

\begin{abstract}
ABSTRAK
Banyaknya perusahaan termasuk perusahaan penyedia jasa saat ini terkena dampak Covid-19 yang melanda negara Indonesia sejak bulan Maret 2020. Kedai Kopi Sang Esoen merupakan salah satu coffee shop yang berada di kota Gresik, berlokasi di Jalan Kyai H. Syafi'i 99, Suci, Gresik. Banyak keluhan yang masuk ke Kedai Kopi Sang Esoen terhadap pelayanan yang telah diberikan. Berdasarkan permasalahan tersebut, maka bagaimana cara memperbaiki masalah yang dihadapi oleh Kedai Kopi Sang Esoen sehingga kualitas pelayanan terhadap pelanggan dapat terpenuhi. Cara agar kualitas pelayanan pada Kedai Kopi Sang Esoen dapat diperbaiki, maka digunakan metode service quality dan metode quality function deployment. Pengolahan data menggunakan metode service quality untuk menunjukkan gap setiap atribut pelayanan, gap negatif terbesar terdapat pada atribut kenyamanan pada meja dan kursi pada Kedai Kopi Sang Esoen dengan nilai gap -0,7375. Sedangkan gap negatif terkecil pada atribut tersedianya fasilitas internet (wifi) yang lancar dengan nilai gap -0,0625. Selanjutnya, atribut dengan nilai gap negatif menjadi voice of customer pada matrik house of quality yang akan diolah lebih lanjut untuk mendapatkan perbaikan. Quality function deployment memberikan hasil rancangan perbaikan kualitas pelayanan berdasarkan matrik house of quality yang seharusnya dilakukan perbaikan oleh pihak Kedai Kopi Sang Esoen dan menghasilkan respon teknis sesuai dengan prioritasnya. Prioritas utama perbaikan dengan nilai 3,374 adalah melakukan training untuk meningkatkan kinerja/kreatifitas karyawan dan memberi penghargaan kepada karyawan yang kinerjanya selalu meningkat serta memberi sanksi kepada karyawan yang kinerjanya buruk.
\end{abstract}

Kata kunci : Pelayanan, Service Quality, Quality Function Deployment

\section{PENDAhUluan}

Persaingan dalam dunia industri sangatlah pesat, pasar bisnis menuntut setiap perusahaan untuk selalu berusaha meningkatkan kualitas produknya. Semua perusahaan baik yang bergerak dalam bidang jasa maupun penyiapan pruduk pasti memiliki tujuan untuk tetap berkembang dan berjalan dengan baik agar dapat mempertahankan dan meningkatkan keuntungan atau laba operasional perusahaan. Dengan menerapkan strategi pemasaran yang efektif melalui pemanfaatan peluang yang ada untuk meningkatkan posisi perusahaan di pasar. Pelanggan akan merasa puas jika jasa atau produk yang diberikan melebihi dari harapannya, sehingga kualitas jasa atau produk mempunyai pengaruh yang penting terhadap kepuasan pelanggan. Kualitas adalah totalitas fitur dan karakteristik produk atau jasa yang bergantung pada kemampuannya untuk memuaskan kebutuhan yang dinyatakan atau tersirat (Kotler \& Keller, 2012). Cara-cara yang dapat ditempuh dalam meningkatkan kualitas pelayanan adalah dengan berusaha untuk mengetahui dan memahami keinginan pelanggan. Dengan adanya timbal balik dari pelanggan maka pihak perusahaan dapat memperbaiki kualitas pelayanan. Menurut Kotler (1997) dalam (Jamily, 2018), kepuasan adalah perasaan senang atau kecewa seseorang yang berasal dari perbandingan antara kesan yang diterima terhadap kinerja (hasil) suatu produk dan harapan-harapannya. Kepuasan pelanggan merupakan faktor yang penting bagi perusahaan, sehingga perusahaan dapat terus berjalan dan berkembang terutama dalam peningkatan kualitas pelayanan.

Peningkatan kualitas pelayanan saat ini sangat penting dalam mendukung peningkatan laba. Banyaknya perusahaan termasuk perusahaan penyedia jasa saat ini terkena dampak Covid-19 yang melanda negara 
Indonesia sejak bulan Maret 2020. Melalui Surat Edaran Nomor 2/2020 tentang lanjutan pencegahan dan penyebaran wabah Corona Virus Disease 2019 (Covid-19) di wilayah kewenangan masing-masing secara berkala. Perusahaan diharapkan melakukan upaya pencegahan dan juga tindakan berupa negoisasi dengan tenaga kerja dalam membahas jalan terbaik untuk perusahaan dan karyawan sehingga perusahaan tidak melakukan pengurangan tenaga kerja. Dalam masa pandemi Covid-19, peningkatan kualitas pelayanan merupakan hal yang sangat penting dilakukan untuk memperoleh hasil yang optimal, sehingga perusahan dapat bertahan sekaligus bersaing pada masa pandemi Covid19 yang melanda hingga saat ini.

Kedai Kopi Sang Esoen adalah salah satu coffee shop yang berada di kota Gresik, berlokasi di Jalan Kyai H. Syafi'i 99, Suci, Gresik. Kedai Kopi Sang Esoen buka setiap hari pukul 10.00 pagi sampai jam 11.00 malam. Kedai Kopi Sang Esoen salah satu coffee shop di Gresik yang menyediakan fasilitas tempat indoor dan outdoor yang dilengkapi dengan internet (wifi) dan juga ruangan $\mathrm{AC}$ dibagian indoor. Coffee shop ini juga menyediakan beberapa menu, untuk menu Coffee Based ada Es Kopi Sang Esoen, Es Kopi Susu, Es Kopi Nyoklat, Es Kopi Kelapa, Es Kopi Susu Aren , Es Kopi Susu Matcha, dan Es Kopi Susu Karamel. Untuk menu Non Caffee Based tersedia Es Matcha Ori, Es Susu Reg, Es Nyoklat, dan Es ONYK. Kedai Kopi Sang Esoen juga melayani pembelian online via Go Food (Gojek) atau Grab, kedua pihak tersebut yang akan mengantar pesanan ke customer. Beberapa fasilitas Kedai Kopi Sang Esoen dapat dilihat pada gambar yang ada di Lampiran 1. Untuk pangsa pasarnya meliputi semua kalangan karena harganya yang terjangkau. Dalam upaya meningkatkan kualitas pelayanan, pihak Kedai Kopi Sang Esoen perlu mengetahui apa permasalahan yang telah terjadi. Maka pihak Kedai Kopi Sang Esoen melakukan penyebaran kuisioner terbuka terlebih dahulu kepada 50 pelanggan Kedai Kopi Sang Esoen. Dari hasil rekapitulasi yang didapat dari penyebaran kuisioner terbuka, maka diperoleh hasil 5 jenis keluhan yang mendominasi dan hasilnya dapat dilihat dari Tabel 1 .
Tabel 1. Keluhan Pelanggan Tahun 2020

\begin{tabular}{|c|c|c|c|c|}
\hline No. & $\begin{array}{c}\text { Jenis } \\
\text { keluhan } \\
\text { pelanggan } \\
\end{array}$ & $\begin{array}{l}\text { Jumlah } \\
\text { responden }\end{array}$ & $\begin{array}{c}\text { Jumlah } \\
\text { data } \\
\text { keluhan }\end{array}$ & Persentase \\
\hline 1. & $\begin{array}{l}\text { Fasilitas } \\
\text { internet } \\
\text { (wifi) yang } \\
\text { kurang } \\
\text { lancar/stabil }\end{array}$ & 50 & 12 & $24 \%$ \\
\hline 2. & $\begin{array}{l}\text { Meja dan } \\
\text { tempat } \\
\text { duduk yang } \\
\text { kurang } \\
\text { nyaman }\end{array}$ & 50 & 20 & $40 \%$ \\
\hline 3. & $\begin{array}{l}\text { Antrian } \\
\text { pemesanan } \\
\text { yang } \\
\text { menumpuk } \\
\text { pada kasir }\end{array}$ & 50 & 15 & $30 \%$ \\
\hline 4. & $\begin{array}{l}\text { Kesiapan } \\
\text { dalam } \\
\text { transaksi } \\
\text { uang } \\
\text { kembalian }\end{array}$ & 50 & 10 & $20 \%$ \\
\hline 5. & $\begin{array}{l}\text { Lamanya } \\
\text { menunggu } \\
\text { pesanan } \\
\text { datang }\end{array}$ & 50 & 18 & $36 \%$ \\
\hline
\end{tabular}

Sumber: Kedai Kopi Sang Esoen

Semakin bertambahnya pesaing dalam hal ini membuat pihak Kedai Kopi Sang Esoen untuk lebih meningkatkan kualitas pelayanan, serta melakukan pengembangan usaha dan upaya memenuhi kebutuhan dan keinginan pelanggan supaya jumlah pengujung meningkat. Dari beberapa pesaing ada 1 cafe yang dijadikan sebagai pembanding benchmarking yaitu Pit-Stop Kopi Gold PPS. Cafe tersebut dipilih karena letak Pit-Stop Kopi Gold PPS yang tidak jauh dari Kedai Kopi Sang Esoen sehingga sangat berpengaruh terhadap persaingan jumlah pelanggan, selain itu dari segi harga menu yang ditawarkan lebih murah, penyajian yang lebih menarik, tempat yang lebih luas dengan bagian indoor, rooftop, dan outdoor, serta tersedianya area parkir yang cukup luas.

\section{METODOLOGI PENELITIAN}

Ada beberapa metode yang dapat digunakan untuk mengukur kepuasan dari suatu layanan. Salah satu metode yang digunakan dalam penelitian ini adalah metode Service 
Quality (ServQual). Service quality didefinisikan sebagai seberapa jauh perbedaan antara kenyataan dan harapan pelanggan atas layanan yang mereka terima (Parasuranman, 1988 dalam (Siregar \& Suliantoro, 2019)). Metode Servqual dapat digunakan untuk membandingkan antara persepsi dan ekspektasi pelanggan terhadap layanan yang telah diberikan pihak penyedia jasa. Metode ini terdapat pengelompokan berbagai jenis atribut barang atau jasa kedalam 5 dimensi kualitas diantaranya yaitu bukti langsung (tangible), kepedulian (emphaty), keandalan (reliability), daya tanggap (responsiveness), dan jaminan (assurance). Dalam metode Servqual dapat mengetahui kesenjangan (gap) yang terjadi antara jasa yang didapatkan pelanggan terhadap jasa yang disediakan oleh penyedia jasa.

Walaupun metode Servqual bisa digunakan sebagai alat untuk mengukur kualitas pelayanan, namun masih terdapat kritik teoritis, operasional, konseptual, dan empiris tentang model ini. Salah satu kritiknya mengenai batasan utama model Servqual yaitu ketidakmampuannya dalam memberikan perbaikan lebih lanjut pada titik lemah yang diidentifikasi dari kualitas layanan (Tan \& Pawitra, 2001). Keterlibatan persepsi, target, dan ketersediaan sumber daya yang dimiliki oleh perusahaan seharusnya diikutsertakan dalam penentuan kriteria-kriteria yang diprioritaskan untuk ditingkatkan kualitas pelayanannya. Hal ini perlu dilakukan agar hasil yang diperoleh objektif dan realistis untuk dilaksanakan, sehingga untuk memecahkan permasalahan tersebut peneliti menggunakan metode lainnya yaitu metode Quality Function Deployment (QFD) yang bertujuan untuk pengembangan dan perbaikan dari keinginan maupun kebutuhan pelanggan dengan melakukan perbandingan terhadap kompetitor lain (Yulianto, 2018). Jadi, pada penelitian ini peneliti menggunakan metode Service Quality yang diintegrasikan dengan metode Quality Function Deployment dengan harapan agar mendapat usulan perbaikan pelayanan yang sesuai keinginan pelanggan dan meningkatkan daya saing Kedai Kopi Sang Esoen.

\section{HASIL DAN PEMBAHASAN}

\subsection{Uji Kecukupan Data}

Mendapatkan jumlah minimum sampel supaya memenuhi uji kecukupan data. Digunakan perhitungan dengan rumus Bernoulli untuk mempresentasikan atau mewakili suatu populasi yang ada. Dengan asumsi jumlah kuesioner yang benar 95\% dan tingkat ketelitian 5\% maka:

$\mathrm{N} \geq \frac{Z^{2}\left(1-\frac{\alpha}{2}\right) \cdot p \cdot q}{e^{2}}$

$\mathrm{N} \geq \frac{(1,96)^{2} X 0,95 \times 0,05}{(0,05)^{2}}$

$\mathrm{N} \geq 72,99 \approx 73$

Dari perhitungan di atas didapat bahwa jumlah sampel penelitian yang diperlukan sebanyak 73 responden. Pada penelitian ini menetapkan 80 responden sehingga telah memenuhi syarat kecukupan Bernoulli.

\subsection{Uji Validitas}

Diperoleh angka kritis ( $\mathrm{r}$ tabel) yaitu 0,223. Dalam penelitian ini, uji validitas dilakukan dengan menggunakan bantuan alat SPSS. Tabel 2, 3, dan 4 merupakan hasil olah SPSS, untuk uji validitas per item. Berikut adalah hasil dari uji validitas kuesioner yang diperoleh:

Tabel 2. Validitas Kuesioner Servqual Persepsi

\begin{tabular}{|c|c|c|c|c|}
\hline Atribut & rhitung & & rtabel & Keterangan \\
\hline $\operatorname{Tg} 1$ & 0,762 & $>$ & 0,223 & Valid \\
\hline $\operatorname{Tg} 2$ & 0,322 & $>$ & 0,223 & Valid \\
\hline $\operatorname{Tg} 3$ & 0,836 & $>$ & 0,223 & Valid \\
\hline $\operatorname{Tg} 4$ & 0,32 & $>$ & 0,223 & Valid \\
\hline $\operatorname{Tg} 5$ & 0,762 & $>$ & 0,223 & Valid \\
\hline Rel 1 & 0,558 & $>$ & 0,223 & Valid \\
\hline Rel 2 & 0,639 & $>$ & 0,223 & Valid \\
\hline Rel 3 & 0,717 & $>$ & 0,223 & Valid \\
\hline Res 1 & 0,235 & $>$ & 0,223 & Valid \\
\hline Res 2 & 0,659 & $>$ & 0,223 & Valid \\
\hline Res 3 & 0,58 & $>$ & 0,223 & Valid \\
\hline Res 4 & 0,695 & $>$ & 0,223 & Valid \\
\hline Ass 1 & 0,741 & $>$ & 0,223 & Valid \\
\hline Ass 2 & 0,761 & $>$ & 0,223 & Valid \\
\hline Ass 3 & 0,772 & $>$ & 0,223 & Valid \\
\hline Ass 4 & 0,820 & $>$ & 0,223 & Valid \\
\hline
\end{tabular}




\begin{tabular}{|c|c|c|c|c|}
\hline Emp 1 & 0,776 & $>$ & 0,223 & Valid \\
\hline Emp 2 & 0,698 & $>$ & 0,223 & Valid \\
\hline Emp 3 & 0,702 & $>$ & 0,223 & Valid \\
\hline Emp 4 & 0,721 & $>$ & 0,223 & Valid \\
\hline
\end{tabular}

Sumber: Data Diolah Menggunakan SPSS

Tabel 3. Validitas Kuesioner Servqual Harapan

\begin{tabular}{|c|c|c|c|c|}
\hline Atribut & rhitung & & rtabel & Keterangan \\
\hline Tg 1 & 0,734 & $>$ & 0,223 & Valid \\
\hline Tg 2 & 0,599 & $>$ & 0,223 & Valid \\
\hline Tg 3 & 0,621 & $>$ & 0,223 & Valid \\
\hline Tg 4 & 0,319 & $>$ & 0,223 & Valid \\
\hline Tg 5 & 0,658 & $>$ & 0,223 & Valid \\
\hline Rel 1 & 0,843 & $>$ & 0,223 & Valid \\
\hline Rel 2 & 0,688 & $>$ & 0,223 & Valid \\
\hline Rel 3 & 0,825 & $>$ & 0,223 & Valid \\
\hline Res 1 & 0,65 & $>$ & 0,223 & Valid \\
\hline Res 2 & 0,507 & $>$ & 0,223 & Valid \\
\hline Res 3 & 0,735 & $>$ & 0,223 & Valid \\
\hline Res 4 & 0,624 & $>$ & 0,223 & Valid \\
\hline Ass 1 & 0,565 & $>$ & 0,223 & Valid \\
\hline Ass 2 & 0,386 & $>$ & 0,223 & Valid \\
\hline Ass 3 & 0,779 & $>$ & 0,223 & Valid \\
\hline Ass 4 & 0,775 & $>$ & 0,223 & Valid \\
\hline Emp 1 & 0,646 & $>$ & 0,223 & Valid \\
\hline Emp 2 & 0,341 & $>$ & 0,223 & Valid \\
\hline Emp 3 & 0,425 & $>$ & 0,223 & Valid \\
\hline Emp 4 & 0,462 & $>$ & 0,223 & Valid \\
\hline Sumbe: Data Dif
\end{tabular}

Sumber: Data Diolah Menggunakan SPSS

Tabel 4. Validitas Kuesioner Servqual Tingkat Kepentingan Kedai Kopi Sang Esoen

\begin{tabular}{|c|c|c|c|c|}
\hline Atribut & rhitung & & rtabel & Keterangan \\
\hline Tg 1 & 0,632 & $>$ & 0,223 & Valid \\
\hline Tg 2 & 0,610 & $>$ & 0,223 & Valid \\
\hline Tg 3 & 0,399 & $>$ & 0,223 & Valid \\
\hline Tg 4 & 0,622 & $>$ & 0,223 & Valid \\
\hline Tg 5 & 0,594 & $>$ & 0,223 & Valid \\
\hline Rel 1 & 0,503 & $>$ & 0,223 & Valid \\
\hline Rel 2 & 0,497 & $>$ & 0,223 & Valid \\
\hline Rel 3 & 0,616 & $>$ & 0,223 & Valid \\
\hline Res 1 & 0,585 & $>$ & 0,223 & Valid \\
\hline
\end{tabular}

\begin{tabular}{|c|c|c|c|c|}
\hline Res 2 & 0,661 & $>$ & 0,223 & Valid \\
\hline Res 3 & 0,625 & $>$ & 0,223 & Valid \\
\hline Res 4 & 0,591 & $>$ & 0,223 & Valid \\
\hline Ass 1 & 0,635 & $>$ & 0,223 & Valid \\
\hline Ass 2 & 0,567 & $>$ & 0,223 & Valid \\
\hline Ass 3 & 0,45 & $>$ & 0,223 & Valid \\
\hline Ass 4 & 0,631 & $>$ & 0,223 & Valid \\
\hline Emp 1 & 0,623 & $>$ & 0,223 & Valid \\
\hline Emp 2 & 0,421 & $>$ & 0,223 & Valid \\
\hline Emp 3 & 0,717 & $>$ & 0,223 & Valid \\
\hline Emp 4 & 0,561 & $>$ & 0,223 & Valid \\
\hline
\end{tabular}

Sumber: Data Diolah Menggunakan SPSS

\subsection{Uji Reliabilitas}

Reliabilitas item dapat dilihat dari nilai alpha cornbach, dari hasil olah SPSS. Jika nilai $\geq 0,7$ maka item dinyatakan reliabel. Dari data Tabel 4.5 dibawah, diketahui bahwa nilai untuk item-item kuesioner servqual persepsi sebesar $0,928 \geq 0,7$ dengan demikian seluruh item persepsi dinyatakan reliabel. Sedangkan untuk nilai item-item servqual harapan pada Tabel 4.6 sebesar $0,907 \geq 0,7$ dengan demikian seluruh item harapan dinyatakan reliabel. Selanjutnya untuk item-item kuesioner tingkat kepentingan pada Tabel 4.7 sebesar $0,892 \geq 0,7$ dengan demikian seluruh item kepentingan dinyatakan reliabel.

\subsection{Perhitungan Gap Servqual}

Dari hasil pengolahan data kuesioner terhadap pelayanan Kedai Kopi Sang Esoen, diperoleh gambaran adanya gap yang terjadi pada pihak pelanggan yaitu antara tingkat persepsi dan tingkat harapan. Gap ini menunjukkan tingkat pelayanan yang telah diberikan Kedai Kopi Sang Esoen terdapat beberapa atribut yang tidak sesuai dengan harapan pelanggan, untuk mengetahui gap ini digunakan nilai rata-rata dari tingkat persepsi dan harapan setiap atribut kebutuhan tersebut. Maka nilai gap untuk setiap atribut dapat dilihat pada Tabel 5 dibawah ini: 
Tabel 5. Hasil Perhitungan Nilai Gap

\begin{tabular}{|c|c|c|c|c|}
\hline No. & Atribut & $\begin{array}{c}\text { Mean } \\
\text { Tingkat } \\
\text { Persepsi }\end{array}$ & $\begin{array}{c}\text { Mean } \\
\text { Tingkat } \\
\text { Harapan }\end{array}$ & Gap \\
\hline 1. & $\operatorname{Tg} 1$ & 4.5125 & 4.1875 & 0.325 \\
\hline 2. & $\operatorname{Tg} 2$ & 3.8375 & 4.1125 & -0.275 \\
\hline 3. & $\operatorname{Tg} 3$ & 4.4 & 4.1625 & 0.2375 \\
\hline 4. & $\operatorname{Tg} 4$ & 3.525 & 4.2625 & -0.7375 \\
\hline 5. & $\operatorname{Tg} 5$ & 4.2625 & 4.325 & -0.0625 \\
\hline 6. & Rel 1 & 4.05 & 4.125 & -0.075 \\
\hline 7. & Rel 2 & 4.4625 & 4.45 & 0.0125 \\
\hline 8. & Rel 3 & 4.125 & 4.3125 & -0.1875 \\
\hline 9. & Res 1 & 3.55 & 3.8625 & -0.3125 \\
\hline 10. & Res 2 & 4.325 & 4.2 & 0.125 \\
\hline 11. & Res 3 & 4.175 & 4.3625 & -0.1875 \\
\hline 12. & Res 4 & 4.2875 & 4.1375 & 0.15 \\
\hline 13. & Ass 1 & 4.3375 & 3.8125 & 0.525 \\
\hline 14. & Ass 2 & 4.275 & 4.0375 & 0.2375 \\
\hline 15. & Ass 3 & 4.375 & 4.225 & 0.15 \\
\hline 16. & Ass 4 & 4.325 & 4.1875 & 0.1375 \\
\hline 17. & Emp 1 & 4.2875 & 3.9625 & 0.325 \\
\hline 18. & Emp 2 & 4.325 & 4.0125 & 0.3125 \\
\hline 19. & Emp 3 & 4.2125 & 3.8875 & 0.325 \\
\hline 20. & Emp 4 & 4.2375 & 3.925 & 0.3125 \\
\hline
\end{tabular}

Sumber: Data Diolah Menggunakan Excel

\subsection{Voice of Customer (VOC)}

Nilai gap yang diperoleh dari hasil perhitungan metode servqual, lalu diranking dari nilai negatif terbesar sampai nilai negatif terkecil. Nilai gap negatif dijadikan sebagai Voice of Customer (VOC) didalam House of Quality (HOQ) yang nantinya akan diolah lebih lanjut untuk dilakukan perbaikan. Hasil dapat dilihat pada Tabel 6 dibawah ini:

Tabel 6. Voice of Customer

\begin{tabular}{|c|l|c|c|}
\hline No. & Atribut Pelayanan & Gap & Rank \\
\hline 1. & $\begin{array}{l}\text { Kenyamanan pada } \\
\text { meja dan kursi } \\
\text { pada Kedai Kopi } \\
\text { Sang Esoen }\end{array}$ & $-0,7375$ & 1 \\
\hline 2. & $\begin{array}{l}\text { Kecepatan } \\
\text { karyawan dalam } \\
\text { melayani } \\
\text { pelanggan }\end{array}$ & $-0,3125$ & 2 \\
\hline
\end{tabular}

\begin{tabular}{|c|l|c|c|}
\hline 3. & $\begin{array}{l}\text { Kondisi fasilitas } \\
\text { toilet dan tempat } \\
\text { ibadah (Musholla) }\end{array}$ & $-0,275$ & 3 \\
\hline 4. & $\begin{array}{l}\text { Kemapuan } \\
\text { penataan } \\
\text { hidangan yang } \\
\text { baik }\end{array}$ & $-0,1875$ & 4 \\
\hline 5. & $\begin{array}{l}\text { Kesiapan kasir } \\
\text { dalam melakukan } \\
\text { transaksi uang }\end{array}$ & $-0,1875$ & 5 \\
\hline 6. & $\begin{array}{l}\text { Memberikan } \\
\text { pelayanan tepat } \\
\text { waktu pada } \\
\text { pesanan } \\
\text { pelanggan }\end{array}$ & $-0,075$ & 6 \\
\hline 7. & $\begin{array}{l}\text { Tersedianya } \\
\text { fasilitas internet } \\
\text { (wifi) yang lancar }\end{array}$ & $-0,0625$ & 7 \\
\hline
\end{tabular}

\subsection{Quality Function Deployment (QFD)}

Analisis QFD yang dianalisis dengan menggunakan House of Quality (HOQ) maka pembentukan House of Quality (HOQ) dimulai dari melakukan penjabaran voice of customer. Lalu melakukan perhitungan planning matrik. Kemudian dilakukan penjabaran perhitungan dari customer need ke technical respon. Hasil pembentukan HOQ dapat dilihat pada gambar di bawah ini. 

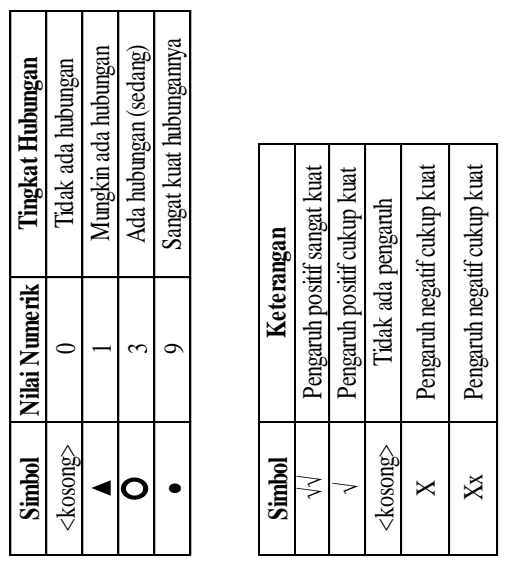

\begin{tabular}{|c|c|c|c|c|c|c|c|}
\hline 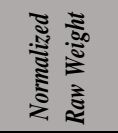 & $\stackrel{\varrho}{\varrho}$ & $\frac{\vec{t}}{0}$ & $\mid \begin{array}{l}0 \\
\stackrel{2}{0} \\
0\end{array}$ & $\frac{\vec{n}}{0}$ & $\frac{\mathrm{a}}{0}$ & 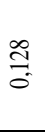 & $\mid \begin{array}{l}0 \\
0 \\
0 \\
0\end{array}$ \\
\hline 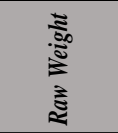 & $\begin{array}{c}\tilde{\sigma} \\
\tilde{\sigma} \\
\sigma\end{array}$ & $\begin{array}{l}0 \\
0 \\
0\end{array}$ & $\begin{array}{c}0 \\
0 \\
i=1\end{array}$ & $\begin{array}{l}\text { Oे. } \\
\text { in } \\
n^{2}\end{array}$ & $\begin{array}{l}\mathscr{0} \\
\stackrel{+}{+}\end{array}$ & $\begin{array}{l}\text { 苋 } \\
\text { f }\end{array}$ & \begin{tabular}{|l|}
0 \\
0 \\
0
\end{tabular} \\
\hline 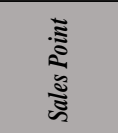 & $\because$ & $\because$ & $\because$ & $\cong$ & $\cong$ & $\cong$ & $\cong$ \\
\hline है & 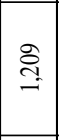 & $\underset{\stackrel{\infty}{:}}{\stackrel{\infty}{=}}$ & : & 导 & 总 & పे & 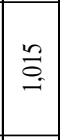 \\
\hline క్ & $\begin{array}{l}\stackrel{8}{8} \\
\stackrel{2}{+}\end{array}$ & $\begin{array}{l}\stackrel{2}{\sigma} \\
\underset{\gamma}{\sigma}\end{array}$ & $\frac{m}{m}$ & 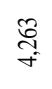 & $\stackrel{\stackrel{\sim}{\Im}}{\underset{f}{*}}$ & $\stackrel{\cong}{\exists}$ & $\mid \begin{array}{l}\tilde{\infty} \\
\infty \\
\sim\end{array}$ \\
\hline 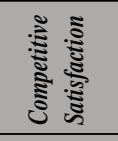 & $\mid \begin{array}{l}\infty \\
\stackrel{0}{0} \\
+\end{array}$ & $\left|\begin{array}{c}0 \\
\infty \\
\infty \\
\tilde{c}\end{array}\right|$ & $\begin{array}{c}\infty \\
\sim\end{array}$ & 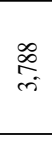 & $\underset{c}{\stackrel{2}{m}}$ & bi & $\mid$\begin{tabular}{|l}
$n$ \\
$\tilde{n}$ \\
$\tilde{n}$
\end{tabular} \\
\hline 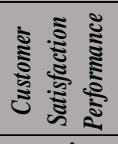 & $\mid$\begin{tabular}{l}
$\mathscr{8}$ \\
\multirow{+}{*}{}
\end{tabular} & $\begin{array}{l}\curvearrowleft \\
\ddots \\
f\end{array}$ & 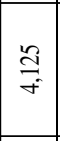 & $\stackrel{\stackrel{\leftrightarrow}{\circ}}{+}$ & $\begin{array}{l}\infty \\
\infty \\
\infty \\
\infty\end{array}$ & $\begin{array}{l}\stackrel{n}{n} \\
m \\
m\end{array}$ & \begin{tabular}{|l}
2 \\
2 \\
0 \\
$m$
\end{tabular} \\
\hline 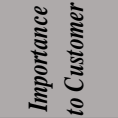 & $\mid \begin{array}{c}\infty \\
\stackrel{\infty}{c} \\
\sim\end{array}$ & $\begin{array}{l}E \\
E \\
m\end{array} \mid$ & $\mid \begin{array}{c}\mathscr{2} \\
\stackrel{m}{m}\end{array}$ & $\stackrel{2}{2}$ & $\underset{m}{F}$ & $\stackrel{m}{m}$ & $m$ \\
\hline
\end{tabular}
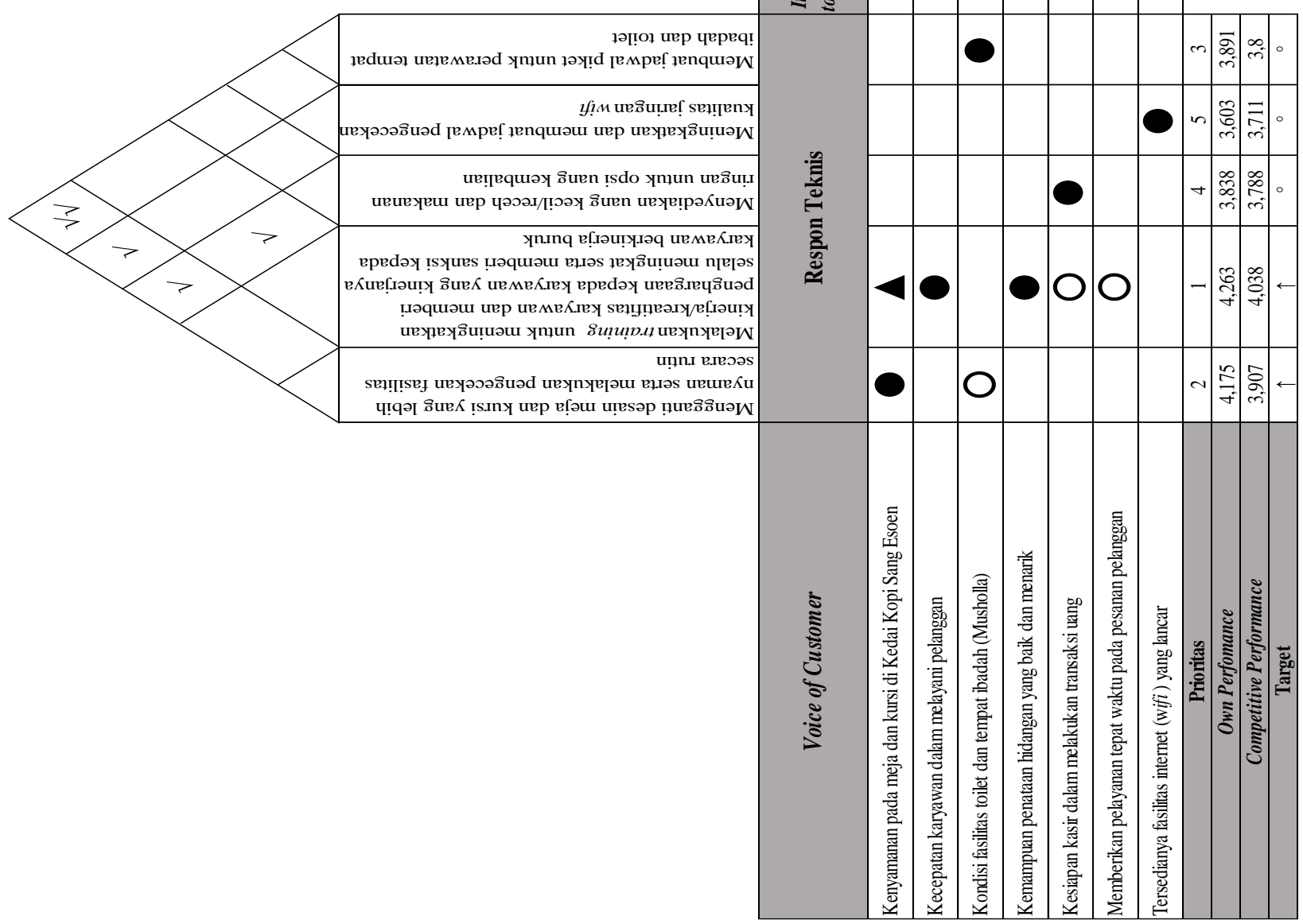


\section{KESIMPULAN}

Berdasarkan hasil analisis dari penelitian yang dilakukan dapat ditarik beberapa kesimpulan yang diantaranya adalah:

1. Dari hasil pengolahan data kuesioner terhadap pelayanan Kedai Kopi Sang Esoen, diperoleh gambaran adanya kesenjangan (gap) yang terjadi pada pihak pelanggan yaitu antara tingkat persepsi dan tingkat harapan. Gap ini menunjukkan tingkat pelayanan yang telah diberikan Kedai Kopi Sang Esoen, terdapat beberapa atribut yang tidak sesuai dengan harapan pelanggan. Berikut adalah atribut-atribut dengan nilai gap negatif yang perlu diperbaiki:

\begin{tabular}{|c|l|c|}
\hline No. & \multicolumn{1}{|c|}{ Atribut Pelayanan } & \multicolumn{1}{c|}{ Gap } \\
\hline 1. & $\begin{array}{l}\text { Kenyamanan pada meja } \\
\text { dan kursi pada Kedai } \\
\text { Kopi Sang Esoen }\end{array}$ & $-0,7375$ \\
\hline 2. & $\begin{array}{l}\text { Kecepatan karyawan } \\
\text { dalam melayani } \\
\text { pelanggan }\end{array}$ & $-0,3125$ \\
\hline 3. & $\begin{array}{l}\text { Kondisi fasilitas toilet } \\
\text { dan tempat ibadah } \\
\text { (Musholla) }\end{array}$ & $-0,275$ \\
\hline 4. & $\begin{array}{l}\text { Kemapuan penataan } \\
\text { hidangan yang baik }\end{array}$ & $-0,1875$ \\
\hline 5. & $\begin{array}{l}\text { Kesiapan kasir dalam } \\
\text { melakukan transaksi } \\
\text { uang }\end{array}$ & $-0,1875$ \\
\hline 6. & $\begin{array}{l}\text { Memberikan pelayanan } \\
\text { tepat waktu pada } \\
\text { pesanan pelanggan }\end{array}$ & $\begin{array}{l}\text { Tersedianya fasilitas } \\
\text { internet (wifi) yang } \\
\text { lancar }\end{array}$ \\
\hline
\end{tabular}

2. Rancangan perbaikan kualitas pelayanan yang seharusnya dilakukan oleh Kedai Kopi Sang Esoen pada masa pandemi Covid-19 berdasarkan prioritasnya sehingga dapat memenuhi kebutuhan pelanggan yaitu sebagai berikut:

a. Mengganti desain meja dan kursi yang lebih nyaman serta melakukan pengecekan fasilitas secara rutin.

b. Melakukan training untuk meningkatkan kinerja/kreatifitas karyawan dan memberi penghargaan kepada karyawan yang kinerjanya selalu meningkat serta memberi sanksi kepada karyawan yang kinerjanya buruk.

c. Menyediakan uang kecil/receh dan makanan ringan untuk opsi uang kembalian.

d. Meningkatkan dan membuat jadwal pengecekan kualitas jaringan wifi.

e. Membuat jadwal piket untuk perawatan tempat ibadah dan toilet.

\section{DAFTAR PUSTAKA}

Alfian, R., \& Putra, A. (2017). Uji Validitas dan Reliabilitas Kuesioner Medication Adherence Report Scale (MARS) Terhadap Pasien Diabetes Mellitus. Jurnal Ilmiah Ibnu Sina, 2(1), 2-18.

Amalina, N. P. (2016). The Analysis of Service Quality Using Quality Function Deployment Method in PT. Hyundai Mobil Indonesia Auto Repair, Bandung. Journal of Accounting and Finance (JAF), 3(1), 3006-3016.

Arikunto, S. (2006). Prosedur Penelitian Suatu Pendekatan Praktik. Jakarta: Rineka Cipta.

Berry, L., Parasuraman, A., \& Zeithaml, V. (1988). SERVQUAL: AMultiple-Item Scale for Measuring Consumer Perceptions of Service Quality. Journal of Retailing, 1(1), 12-40.

Cohen, L. (1995). Quality Function Deployment:How to Make QFD Work for You. USA: Addison-Wesley Publishing Company.

Djarwanto. (1994). Statistik Induktif. Yogyakarta: BPFE.

Efendi, A., Kusmindari, C. D., \& Renilaili. (2020). Peningkatan Kualitas Layanan Konsumen Dengan Metode Servqual dan QFD (Studi Kasus di CV. Sinar Jaya Agung). Bina Darma Conference on Engineering Science, 2(1), 382-391. 
Indriantoro, N. (2002). Metodologi Penelitian Bisnis untuk Akutansi dan Manajemen. Yogyakarta: BPFE.

Jamily, M. H. (2018). Meningkatkan Kualitas Pelayanan di Laundry Thoyyiba Dengan Menggunakan Metode Servqual dan Quality Function Deployment. Gresik: Skripsi. Fakultas Teknik, Teknik Industri, Universitas Muhammadiyah Gresik.

Kotler, \& Keller. (2012). Manajemen Pemasaran. Jakarta: Erlangga.

Margono, S., \& Yuniarko, T. (2019). Penggunaan Metode Servqual Untuk Analisis Pelayanan Jasa Bengkel Studi Kasus Bengkel Kencana Motor Depok. Incomtech, 8(1), 6-15.

Nasikh, A. R. (2018). Pengukuran Kualitas Pelayanan Pasien BPJS di UPT. Puskesmas Alun-Alun Gresik Dengan Menggunakan Metode Servqual dan AHP. Gresik: Skripsi. Fakultas Teknik, Teknik Industri, Universitas Muhammadiyah Gresik.

Putri, R. N., Harsono, A., \& Arijanto, S. (2016). Usulan Perbaikan Kualitas Pelayanan di Cafe X Dengan Menggunakan Metode Dineserv dan Service Quality (Servqual). Jurnal Online Institut Teknologi Nasional, 4(1), 287-298.

Sandjaja, I. E., \& Purnamasari, D. (2017). Perancangan Kuesioner Survei Galangan. Technology Science and Engineering Journal, 1(1), 27-33.

Singaribun, M. (2006). Metode Penelitian Survai. Jakarta: Grassindo.

Siregar, S. D., \& Suliantoro, H. (2019). Meningkatkan Kepuasan Pelanggan Terhadap Kualitas Layanan Wifi ID Dengan Metode Service Quality (Studi Kasus PT. Telkom Indonesia Regional 1 Sumatera). Industrial Engineering Online Journal, 7(1), 1-10.

Sugiyono. (2016). Metode Penelitian Kuantitatif, Kualitatif, dan $R \& D$. Bandung: ALFABETA cv.

Sularto, L. (2020). Analisis Kualitas Layanan Penyedia Data di Indonesia Menggunakan Metode Servqual. Jurnal Teknologi Informasi dan Ilmu Komputer (JTIIK), 7(1), 1-7.

Tan, K. C., \& Pawitra, T. A. (2001). Integrating Servqual and Kano's Model Into QFD for Service Excellence Development. Managing Service Quality. An International Journal, 11(6), 418-430. doi:10.1108/eum0000000006520

Tjiptono, F., \& Chandra, G. (2019). Service Quality \& Customer Satisfaction (5 ed.). Yogyakarta: ANDI.

Umar, H. (2005). Riset Sumber Daya Manusia. Jakarta: PT. Gramedia Pustaka Utama.

Wijaya, T. (2018). Manajemen Kualitas Jasa : Desain Servqual, QFD, dan Kano (2 ed.). Jakarta: PT Indeks.

Y, A. N., Purnamawati, E., \& Suryadi, A. (2020). Analisis Peningkatan Kualitas Pelayanan Dengan Metode Servqual dan Triz (Studi Kasus Pada Cafe XYZ). Jurnal Manajemen Industri dan Teknologi, 1(1), 76-86.

Yulianto, E. E. (2018). Analisis Kualitas Pelayanan Dengan Metode Servqual dan QFD Pada Restoran Carnis Surabaya. Indonesia Natural Research Pharmaceutical Journal (INRPJ), 1(1), 5.

Yusup, F. (2018). Uji Validitas dan Reliabilitas Instrumen Penelitian Kuantitatif. Jurnal Ilmiah Kependidikan, 7(1), 6788. 